\title{
Species richness and diversity in shrub savanna using ordinary kriging
}

\author{
Anderson Pedro Bernardina Batista(1), José Márcio de Mello(1), Marcel Régis Raimundo(1), \\ Henrique Ferraço Scolforo(2), Aliny Aparecida dos Reis ${ }^{(1)}$ and José Roberto Soares Scolforo ${ }^{(1)}$
}

\begin{abstract}
(1)Universidade Federal de Lavras, Departamento de Ciências Florestais, Caixa Postal 3037, CEP $37200-000$ Lavras, MG, Brazil. E-mail: anderson_pedro22@yahoo.com.br, josemarcio@dcf.ufla.br, marcelufla@gmail.com, alinyreis@hotmail.com, jscolforo@dcf.ufla.br (2)North Carolina State University, College of Natural Resources, Department of Forestry and Environmental Resources, 2820 Faucette Drive, 27695 Raleigh, North Carolina, United States. E-mail: hfscolfo@ncsu.edu
\end{abstract}

\begin{abstract}
The objective of this work was to analyze the spatial distribution and the behavior of species richness and diversity in a shrub savanna fragment, in 2003 and 2014, using ordinary kriging, in the state of Minas Gerais, Brazil. In both evaluation years, the measurements were performed in a fragment with 236.85 hectares, in which individual trees were measured and identified across 40 plots $\left(1,000 \mathrm{~m}^{2}\right)$. Species richness was determined by the total number of species in each plot, and diversity by the Shannon diversity index. For the variogram study, spatial models were fitted and selected. Then, ordinary kriging was applied and the spatial distribution of the assessed variables was described. A strong spatial dependence was observed between species richness and diversity by the Shannon diversity index ( $<25 \%$ spatial dependence degree). Areas of low and high species diversity and richness were found in the shrub savanna fragment. Spatial distribution behavior shows relative stability regarding the number of species and the Shannon diversity index in the evaluated years.

Index terms: geostatistics, Shannon index, variogram.

\section{Riqueza e diversidade de espécies em um fragmento de campo cerrado por meio de krigagem ordinária}

\begin{abstract}
Resumo - O objetivo deste trabalho foi analisar a distribuição espacial e o comportamento da riqueza e da diversidade de espécies em um fragmento de campo cerrado, em 2003 e 2014, por meio de krigagem ordinária, no Estado de Minas Gerais. Nos dois anos de monitoramento, as avaliações foram realizadas em um fragmento de 236,85 hectares, em que indivíduos arbóreos foram medidos e identificados em 40 parcelas $\left(1.000 \mathrm{~m}^{2}\right)$. A riqueza foi determinada pelo número de espécies em cada parcela, e a diversidade, pelo índice de diversidade de Shannon. Para o estudo variográfico, foram realizados ajuste e seleção de modelos espaciais. Posteriormente, foi aplicada krigagem ordinária e descrita a distribuição espacial das variáveis avaliadas. Observou-se forte dependência espacial entre riqueza e diversidade de espécies pelo índice de diversidade de Shannon $(<25 \%$ de grau de dependência espacial). Áreas de baixa e alta diversidade e riqueza de espécies foram identificadas no fragmento de campo cerrado. O comportamento da distribuição espacial mostra relativa estabilidade quanto ao número de espécies e ao índice de diversidade de Shannon nos anos avaliados.
\end{abstract}

Termos para indexação: geoestatística, índice de Shannon, variograma.

\section{Introduction}

The Brazilian savanna, also known as Cerrado, is one of the richest and most endangered worldwide (Felfili \& Felfili, 2001; Ritter et al., 2010). This biome is internationally recognized for its importance in the conservation of the world's biodiversity (Myers et al., 2000). In general, knowledge on biodiversity for its conservation is mainly based on floristic composition and species richness (Nogueira et al., 2008; Durigan, 2012).
Richness refers to the total number of species present in a given area, whereas quantitative diversity includes not only the number of species, but also a relative abundance measure (Magurran, 2004). Diversity can be characterized into three categories: alpha, which corresponds to the diversity within a habitat; beta, representing the diversity among habitats, i.e., how species composition varies from place to place; and gamma, which corresponds to large areas, such as biome and continent (Whittaker, 1972; Magurran, 2004). 
The total number of species in a community is often obtained by sampling and is intrinsically linked to sample size (Durigan, 2012). The higher the sampling effort, the closer the number of sampled species will be to the real value of the community (Nogueira et al., 2008). Durigan (2012) and Rocchini et al. (2015) pointed out the challenges faced by studies on diversity and richness, which require a high sampling effort that will significantly impact the results produced and forest inventory costs.

An alternative is to use spatial statistical techniques, since they provide information about the spatial dependence structure of quantitative and qualitative variables. Kriging is the most used spatial interpolator to estimate values for unsampled areas according to the spatial dependence of the studied variable (Isaaks \& Srivastava, 1989).

Several researches have been conducted using dendrometric variables in forests, showing the advantage of adopting these techniques (Pereira et al., 2011; Amaral et al., 2013; Pelissari et al., 2014; Scolforo et al., 2015). However, studies seeking to map the spatial distribution of diversity behavior and species richness are still scarce in the literature.

Geostatistical techniques can be helpful in estimating community diversity, identifying areas of low and high diversity, as well as species richness. In addition, these techniques also allow understanding the spatial pattern of the species richness (S) and Shannon diversity index $\left(\mathrm{H}^{\prime}\right)$ variables in different years, which are fundamental in planning conservation (Hernández-Stefanoni et al., 2011).

Líbano \& Felfili (2006) showed that studies using temporal monitoring enable the evaluation of the effectiveness of the size of conservation areas and of the maintainability capacity of the community over time. Furthermore, these studies indicate potential species for reforestation programs, aiming to guide decision-making regarding the conservation and management of natural areas.

The objective of this work was to analyze the spatial distribution and the behavior of species richness and diversity in a shrub savanna fragment, in 2003 and 2014, using ordinary kriging, in the state of Minas Gerais, Brazil.

\section{Materials and Methods}

The study was conducted in a shrub savanna fragment of 236.85 hectares, located in the municipality of Brasilândia de Minas, in the state of Minas Gerais, Brazil (Figure 1), which presents annual average rainfall of $1,285.92 \mathrm{~mm}$ and average temperature of $22.95^{\circ} \mathrm{C}$. The soil of the area is classified as a Latossolo, i.e., an Oxisol (Scolforo et al., 2008).

The sample design applied to the fragment was systematic sampling (Scolforo et al., 2008). A total of 40 plots with fixed areas of 1,000 $\mathrm{m}^{2}(10 \times 100 \mathrm{~m})$ were installed. In each plot, diameter at breast height (DBH) greater than or equal to $5 \mathrm{~cm}$ and total height were registered in 2003 and 2014, the experimental years. These traits were remeasured in 2014, when ingrowth and dead trees were also identified. All the measured trees were labeled for future measurements and identified according to their specific species, using collected botanical material. Exsiccatae were then produced and stored at the herbarium of Universidade Federal de Lavras, in the state of Minas Gerais, Brazil.

For each sample, the total number of individual trees and species was recorded. The $\mathrm{S}$ variable was calculated by considering the total number of species in each sample, whereas H' was determined per sample - in which the higher the values for H', the higher the species diversity -, using the vegan package (Oksanen et al., 2013) of the R software (R Core Team, 2013). This index also accounts for the number of species and equability (Magurran, 2004). The H' and S values were associated to the central coordinate of each sample unit, enabling the use of geostatistical techniques.

Preliminary data analysis was also performed in order to verify the general behavior of the $\mathrm{S}$ and $\mathrm{H}^{\prime}$ variables. This analysis evaluated: position and dispersion measurements, possible trends in $\mathrm{H}^{\prime}$ and $\mathrm{S}$ as a function of latitude and longitude, and presence of outliers (Mello et al., 2008).

The variographic study consisted of fitting and selecting spatial models. The spherical, exponential, and Gaussian models were fitted by the ordinary least squares method, as described by Mello et al. (2005).

The selection of the models with best performance was based on autovalidation criteria, Akaike's information criterion (AIC), and spatial dependence degree. The spatial dependence degree was calculated as the ratio between nugget effect and sill parameters, expressed in percentage: greater than $75 \%$, indicating weak spatial dependence; between 25 and $75 \%$, moderate spatial dependence; and up to $25 \%$, strong spatial dependence (Cambardella et al., 1994).

Pesq. agropec. bras., Brasília, v.51, n.8, p.958-966, ago. 2016 DOI: 10.1590/S0100-204X2016000800008 
After fitting and selecting of the spatial models, ordinary kriging was applied. Therefore, the spatial distribution of S and H' in 2003 and 2014 for the shrub savanna fragment was obtained by applying ordinary kriging, which is a linear and unbiased estimator with low variance (Isaaks \& Srivastava, 1989). All the analyses were performed using the geoR package (Ribeiro Jr \& Diglle, 2001).

The spatial distribution for S and H' (thematic maps) between the two evaluated time periods (2003 and 2014) was compared using the values of the fitted parameters (nugget effect, sill, and range); and the behavior and shape of the semivariograms was determined through the scaled semivariogram for 2003 and 2014.

Moreover, the correlation between the kriging maps was calculated for each variable of interest, i.e., $\mathrm{S}$ and H', generated for 2003 and 2014. This calculation was carried out in the Spatial Analyst module of the ArcMap software, with the aid of the Multivariate toolset of Band Collection Statistics (Environmental Systems Research Institute, Redlands, CA, USA). This tool performs an analysis of the variable's pixel-pixel values between the maps (the size of the pixels must be common between maps) in order to check the correlation of spatial distribution.

When analyzing $\mathrm{S}$ and $\mathrm{H}^{\prime}$ separately, the interpretation is as follows: the higher the correlation values between the kriging maps of 2003 and 2014, the lower the difference in the distribution pattern of the variables in the evaluated shrub savanna fragment for the assessed years. Therefore, high levels of correlation indicate high similarity in the spatial distribution of the studied variables.

\section{Results and Discussion}

In 2003, 2,729 individual trees belonging to 97 species distributed in the 40 evaluated plots were recorded. In 2014, 11 years later, 2,808 individual trees and 97 species were verified in the same plots. Basically, the total number of species remained the same with an increase in the total number of trees.

The species with a higher number of individual trees were: Eugenia dysenterica DC., with 348 and 353 individual trees in 2003 and 2014, respectively; and Kielmeyera coriacea Mart. \& Zucc., with 221 and 242 individual trees. In addition, 12 species, each with one individual tree, differed between 2003 and 2014. Six of the species measured in 2003, for example, were no longer observed in 2014, including: Aegiphila sellowiana Cham., Dalbergia miscolobium Benth., Eremanthus glomerulatus Less., and Himatanthus obovatus (Müll.Arg.) Woodson. The species Acosmium dasycarpum (Vogel) Yakovlev, Bauhinia longifolia

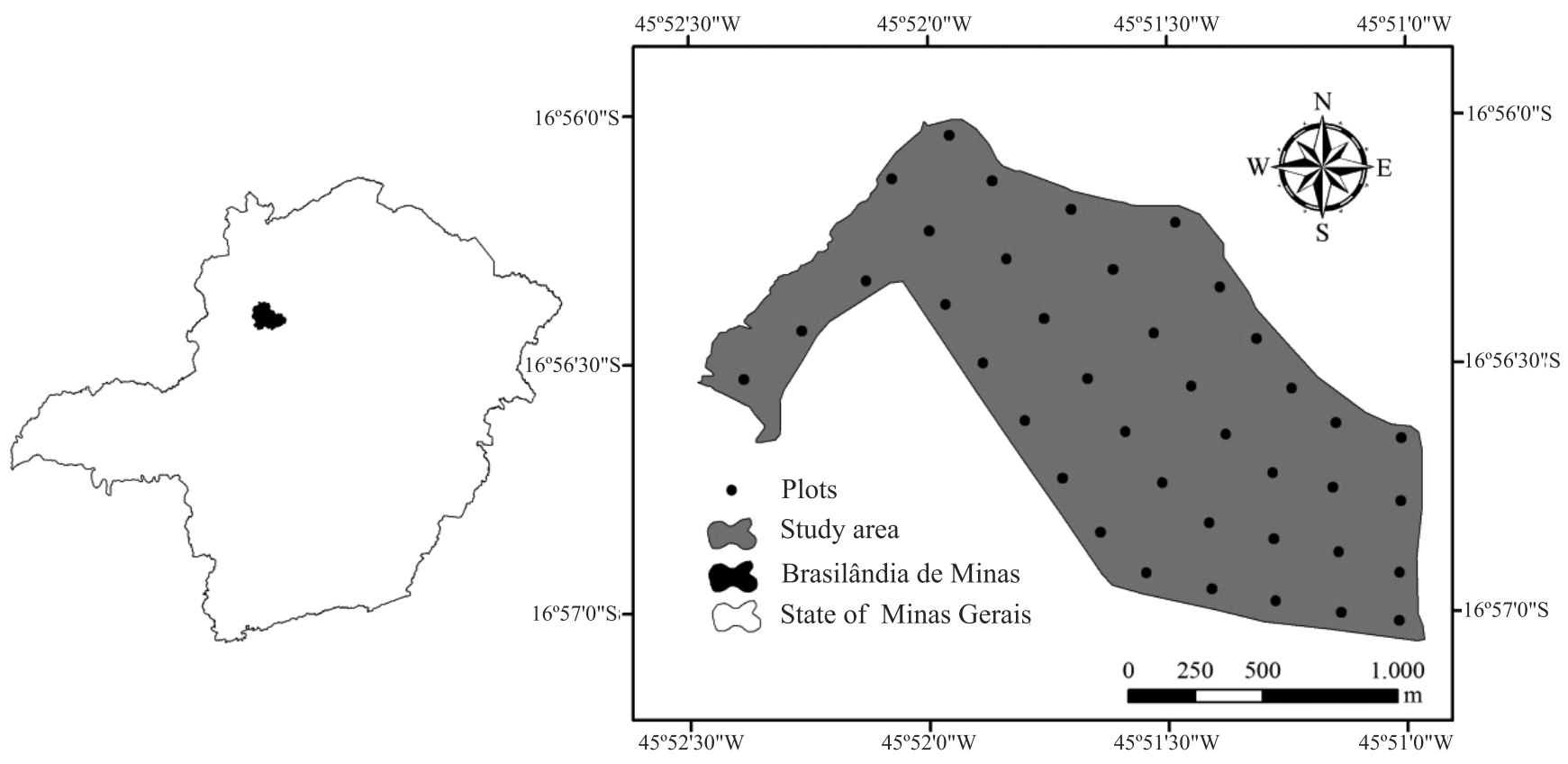

Figure 1. Location of study area, i.e., shrub savanna fragment, in the state of Minas Gerais, Brazil. 
D.Dietr., Copaifera langsdorffii Desf., and Xylopia sericea A.St.-Hil. measured in 2014 were not registered in 2003.

Almeida et al. (2014), while studying a savanna fragment, found similar results, in which species with low abundance appeared and disappeared in the different assessed years. According to Aquino et al. (2007), these species present a fluctuating population over the years, since several factors easily increase their mortality and ingrowth rate.

The coefficient of variation $(\mathrm{CV})$ for $\mathrm{S}$ revealed a minimal change in the total number of species in the shrub savanna fragment between 2003 and 2014 (Table 1); the CV for H' also presented minor changes. These CV values are important, because variance can impact the quality of the fitted spatial models. This indicates that data variation can lead to a larger error in the interpolation.

The general $\mathrm{H}$ ' found in the studied fragment in 2003 and 2014 was of 3.64 and 3.63, respectively. These values indicate a relative stability (constancy) in this variable for the experimental years.

Felfili \& Felfili (2001) studied alpha diversity at six sites with predominant savanna vegetation and found values around 3 for the H' variable. According to Felfili et al. (2000), an H' variable starting at 3 is considered high.

Similar results were observed in the present study regarding diversity when compared to those obtained by Felfili et al. (2000), highlighting the high diversity of the shrub savanna fragment, as well as its importance from a conservation point of view (Oliveira et al., 2015).

For S and H', the minimum, maximum, position, and dispersion measurements were very similar in the evaluated years. These results show little change in diversity and species richness. It should be noted that the two species with highest abundance, E. dysenterica

Table 1. Descriptive statistics of species richness (S) and diversity ( $\left.\mathrm{H}^{\prime}\right)$ in the evaluated shrub savanna fragment, in the state of Minas Gerais, Brazil, in 2003 and 2014 ${ }^{(1)}$.

\begin{tabular}{ccccccc}
\hline Year & Variable & Minimum & Maximum & Average & SD & CV (\%) \\
\hline \multirow{2}{*}{2003} & S & 5.0 & 38 & 23.30 & 7.19 & 30.87 \\
& H' & 1.56 & 3.36 & 2.74 & 0.39 & 14.44 \\
\hline \multirow{2}{*}{2014} & S & 5.0 & 37 & 23.42 & 6.47 & 27.63 \\
& H' & 1.49 & 3.32 & 2.73 & 0.39 & 14.22 \\
\hline
\end{tabular}

${ }^{(1)} \mathrm{SD}$, standard deviation; $\mathrm{CV}$, coeficient of variation. and K. coriacea, were the same for 2003 and 2014. This emphasizes the stability of the study area in regards to species composition, which shows minor changes over time.

Understanding species richness and diversity allows defining regions in which these variables are low and high, enabling the identification of priority areas regarding conservation and reforestation. Observing the behavior of these variables in different years also allows identifying changes in forest areas, which is why spatial studies were carried out in different years for the assessed shrub savanna fragment.

Spatial analysis started with the variographic study previously described. The average error and standard deviation by autovalidation and AIC did not differ significantly among the fitted models (Table 2). Therefore, the spatial dependence degree was chosen as the main criteria to determine the most adequate fitted models for the H' and S variables in 2003 and 2014.

The fitted spherical model was selected to describe spatial distribution, since it presented a better fitting, according to the experimental semivariogram of $\mathrm{S}$ and $H^{\prime}$ in 2003 and 2014. Amaral et al. (2013) and Hernández-Stefanoni et al. (2012) also used the spherical model to spatially describe $H^{\prime}$ in a rain forest fragment and $\mathrm{S}$ in a tropical native Mexican forest, respectively.

These models are properly fitted for empirical semivariograms, which show the spatial structure for the variables evaluated in each period of time (Figure 2).

There was a great similarity in the spatial dependence structure between 2003 and 2014 for each variable, which reinforces the proximity of the fitted parameters (Table 2).

Table 2. Autovalidation statistics, Akaike's information criterion (AIC), and spatial dependence degree (SDD) for the spherical model and their respective parameters ${ }^{(1)}$.

\begin{tabular}{ccccccccc}
\hline \multicolumn{2}{l}{ Year Variable } & EMR & DEMR & AIC & Co & C & A & SDD (\%) \\
\hline \multirow{2}{*}{2003} & S & 0.0013 & 0.986 & -132.0 & 7 & 45.53 & 673.59 & 13.32 \\
& H' & 0.0045 & 1.021 & -15.88 & 0.03 & 0.14 & 953.02 & 17.64 \\
\hline \multirow{2}{*}{2014} & S & 0.0009 & 1.069 & -130.5 & 10 & 32.53 & 743.85 & 23.51 \\
& H' & 0.0029 & 1.092 & -17.29 & 0.03 & 0.12 & 801.73 & 20.00 \\
\hline
\end{tabular}

${ }^{(1)} \mathrm{EMR}$, average reduced error; DEMR, average reduced standard error; Co, nugget effect; $\mathrm{C}$, sill; and $\mathrm{A}$, range in meters for species richness $(\mathrm{S})$ and diversity (H').

Pesq. agropec. bras., Brasília, v.51, n.8, p.958-966, ago. 2016 DOI: 10.1590/S0100-204X2016000800008 
The relative similarity between the fitted models for each variable in the studied years enables a new approach in spatiotemporal monitoring. In this sense, through the scaled semivariograms (Figure 3), it was possible to observe a similarity between the fitted models for the different variables, especially for $\mathrm{S}$, for which the curves overlapped, although, for H', a high similarity was also found.

The range for the H' variable was lower in 2014 when compared to 2003, and was directly affected by the values of the spatial dependence degree (Table 2). This result shows a greater variation not explained by the fitted model. Since the random effect (nugget effect) increased by 2014 , the range consequently decreased. In this condition, the combination of pairs of points should occur at shorter distances.
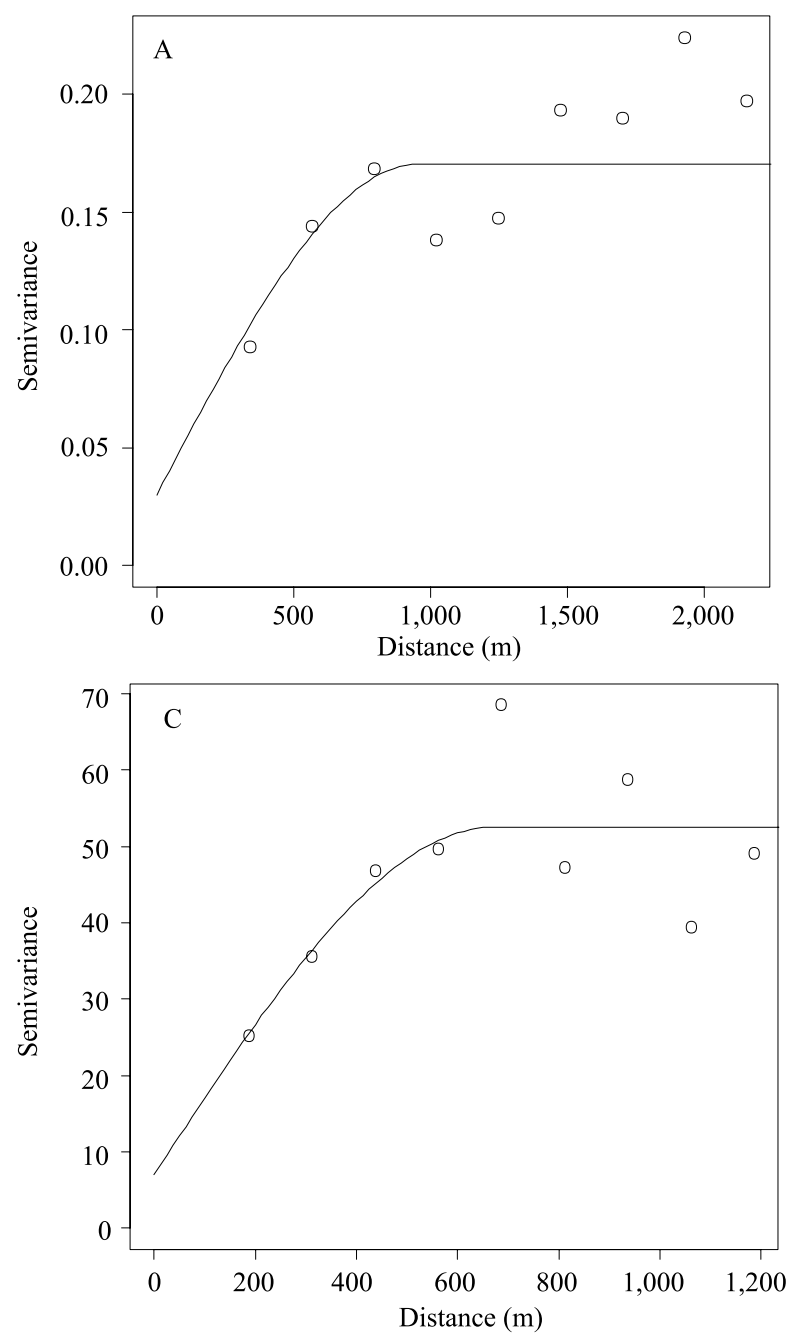

As a reflection of the decrease in range and of the increase in random effect, there was a slight reduction in general H', from 3.64 to 3.63 , between 2003 and 2014 , for the shrub savanna fragment. Geostatistical techniques showed the same pattern of the traditional method; however, through kriging, it was possible to evaluate the behavior of $\mathrm{S}$ and $\mathrm{H}^{\prime}$ in the studied area. If only $\mathrm{H}^{\prime}$ values were used, it would not possible to infer about the regions of low and high diversity. Therefore, spatial analysis aggregates valuable information for each measurement and also for comparing measurements in different years.

It should be highlighted that the slight decrease in $H^{\prime}$ values may be signifying a change in the level of species diversity, which was affected by the range parameter, i.e., $953.02 \mathrm{~m}$ in 2003 and $801.73 \mathrm{~m}$ in
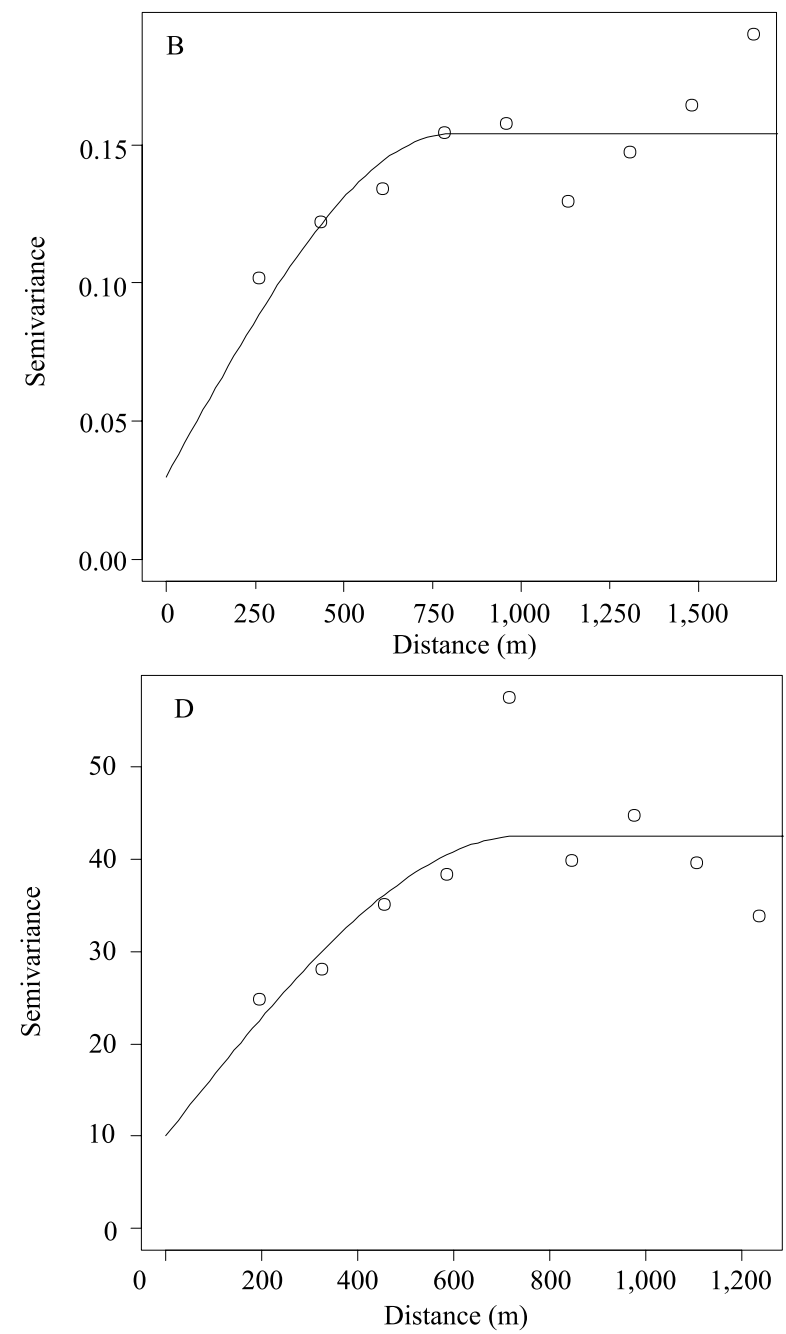

Figure 2. Fitted spherical model for species diversity in 2003 (A) and 2014 (B), as well as fitted spherical model for species richness in 2003 (C) and 2014 (D), in the evaluated shrub savanna fragment, in the state of Minas Gerais, Brazil. 
2014. In other words, the spatial dependence degree decreased over time.

Range decreases can be a result of changes in the landscape (Sertel et al., 2007; Acerbi Junior et al., 2015). Acerbi Junior et al. (2015) used scaled semivariograms to detect modifications in the spatial structure of the Brazilian savanna after deforestation and found that the change in the range parameter was the most significant.

In the present study, kriging maps were used to describe the spatial distribution of the studied variables both in 2003 and 2014, and areas with a high number of species and with higher species diversity were identified (Figure 4). This shows that the spatial behavior of the $\mathrm{S}$ and $\mathrm{H}$ ' variables allows to identify areas with the highest values and greatest differences, as well as the correlation between these variables. Areas that presented higher $\mathrm{S}$ values, that is, total number of species, were also the ones with greater diversity. It should be noted that these high values of $\mathrm{S}$ and $\mathrm{H}^{\prime}$ occurred in areas near the river stream.

Since ordinary kriging is a consequence of the quality of the fitted models and all the models fitted adequately in the semivariograms, it is possible to ensure that the estimates for each variable are reliable. The average reduced error and the average reduced standard error obtained in the autovalidation were close to 0 and 1 (Cressie, 1993), respectively, which shows the quality of the estimates (Table 2). This point is very important, since the quality of ordinary kriging maps is dependent on the quality of the fitted models (Scolforo et al., 2015). This fact suggests that kriging maps and scaled semivariograms for different measurement years enable the detection of changes, even in a reduced scale. Between 2003 and 2014, high correlations of 0.93 and 0.95 , respectively, were observed both between S maps and between H' maps. These correlation values allow inferencing that both variables showed a similar spatial behavior in the evaluated years. The similarity in the fitted models, scaled semivariograms, and ordinary kriging maps for each variable over time shows that the shrub savanna fragment is probably in a constant state.

Almeida et al. (2014), while monitoring a savanna forest fragment for 27 years, also detected minor changes in forest composition, which was characterized as stable, with a minor fluctuation in its density.

Temporal analysis has resulted in relevant data on the dynamics of the savanna vegetation. Temporal monitoring of biodiversity that takes into account species composition, demographics, ingrowth, growth, mortality, and biomass yield provides information on the operation of communities in the long term and on the response of some occasional disturbances (Líbano \& Felfili, 2006).

Therefore, the present study shows that the evaluated shrub savanna fragment presents relative
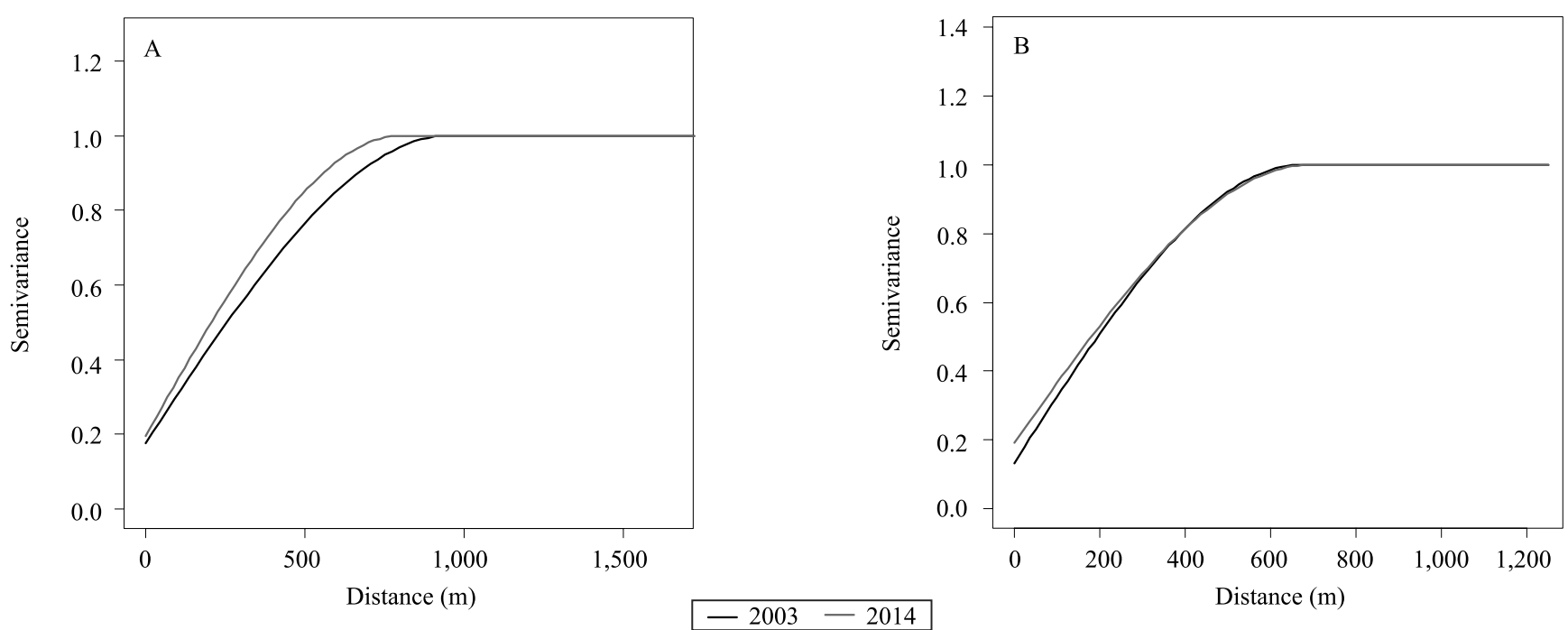

Figure 3. Scaled semivariogram of the fitted models for species diversity (A) and richness (B), in 2003 and 2014, in the evaluated shrub savanna fragment, in the state of Minas Gerais, Brazil. 

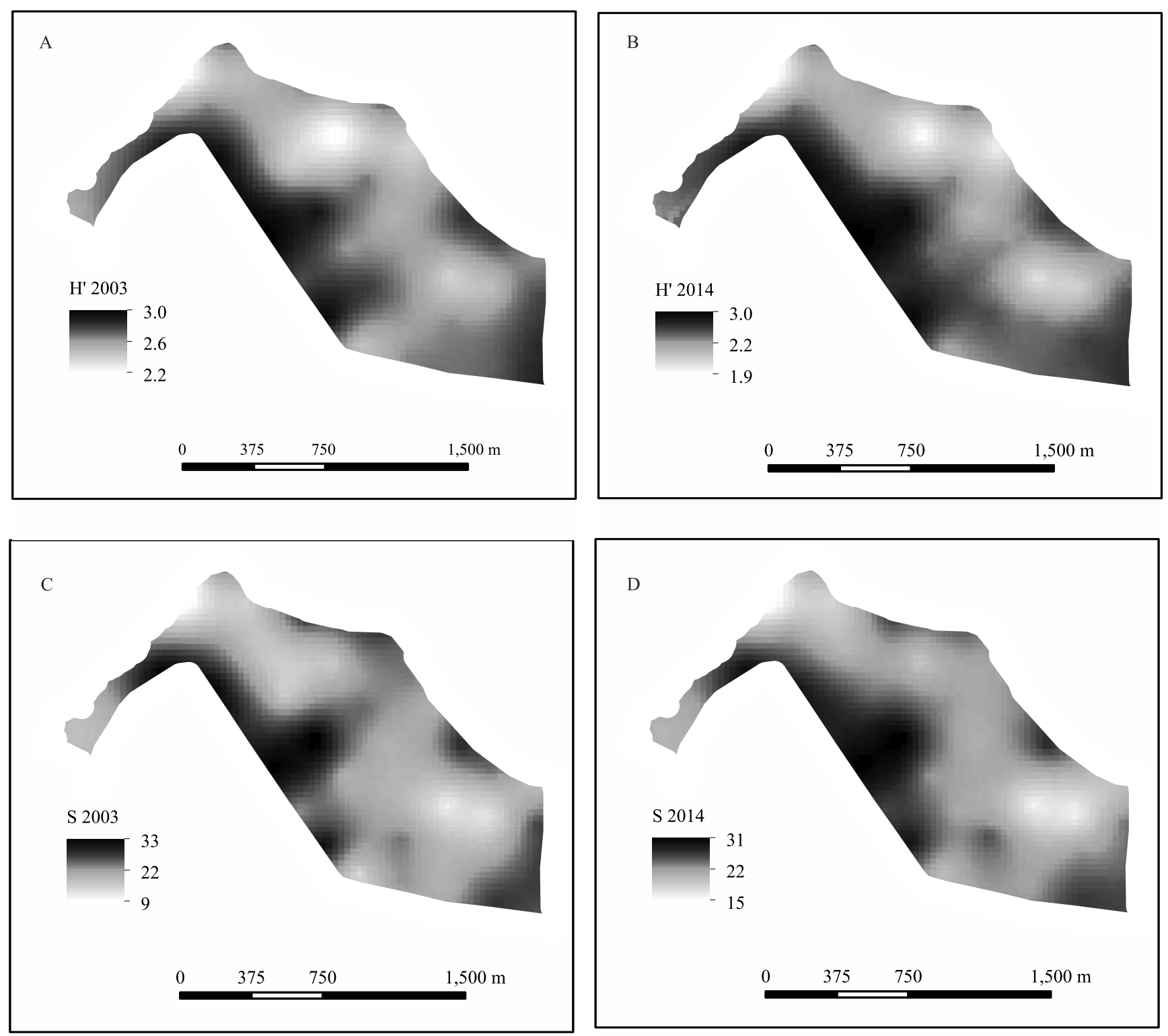

Figure 4. Ordinary kriging maps for species diversity (H') in 2003 (A) and 2014 (B), as well as species richness (S) in 2003 (C) and 2014 (D), in the evaluated shrub savanna fragment, in the state of Minas Gerais, Brazil.

stability regarding the spatial continuity behavior of the S and H' variables in 2003 and 2014. S and H' mapping provides relevant information related to the spatial distribution of a fragment over time, especially in identifying regions of low and high species diversity and richness. Rocchini et al. (2015) highlighted that the identification of species variation is a critical point and a challenge for future studies on spatial ecology. This mapping could assist in the application of forest inventory efforts, in the management and conservation planning of native forests.

\section{Conclusions}

1. A strong spatial dependence structure is observed between the variables species richness and diversity in 2003 and 2014.

2. The spatial distribution behavior for 2003 and 2014 shows relative numerical and spatial stability regarding the total number of species and the Shannon diversity index, since areas with low and high values for both variables presented minor changes.

3. Ordinary kriging is effective in mapping species diversity and richness. 


\section{References}

ACERBI JUNIOR, F.W.; SILVEIRA, E.M. de O.; MELLO, J.M. de; MELLO, C.R. de; SCOLFORO, J.R.S. Change detection in Brazilian savannas using semivariograms derived from NDVI images. Ciência e Agrotecnologia, v.39, p.103-109, 2015. DOI: 10.1590/S1413-70542015000200001.

ALMEIDA, R.F.; FAGG, C.W.; OLIVEIRA, M.C. de; MUNHOZ, C.B.R.; LIMA, A.S. de; OLIVEIRA, L.S.B. de. Mudanças florísticas e estruturais no cerrado sensu stricto ao longo de 27 anos (1985-2012) na Fazenda Água Limpa, Brasília, DF. Rodriguésia, v.65, p.001-019, 2014.

AMARAL, L. de P.; FERREIRA, R.A.; LISBOA, G. do S.; LONGHI, S.J.; WATZLAWICK, L.F. Variabilidade espacial do Índice de Diversidade de Shannon-Wiener em Floresta Ombrófila Mista. Scientia Forestalis, v.41, p.83-93, 2013.

AQUINO, F. de G.; WALTER, B.M.T.; RIBEIRO, J.F. Woody community dynamics in two fragments of "cerrado" stricto sensu over a seven-year period (1995-2002), MA, Brazil. Revista Brasileira de Botânica, v.30, p.113-121, 2007. DOI: 10.1590/ S0100-84042007000100011.

CAMBARDELLA, C.A.; MOORMAN, T.B.; NOVAK, J.M.; PARKIN, T.B.; KARLEN, D.L.; TURCO, R.F.; KONOPKA, A.E. Field scale variability of soil properties in central Iowa soils. Soil Science Society of America Journal, v.58, p.1501-1511, 1994. DOI: $10.2136 /$ sssaj1994.03615995005800050033x.

CRESSIE, N.A.C. Statistics for spatial data. rev. ed. New York: J. Wiley \& Sons, 1993. 900p.

DURIGAN, G. Estrutura e diversidade de comunidades florestais. In: MARTINS, S.V. Ecologia de florestas tropicais do Brasil. 2.ed. rev. e ampl. Viçosa: UFV, 2012. p.294-325.

FELFILI, J.M.; REZENDE, A.V.; SILVA JÚNIOR, M.C. da; SILVA, M.A. Changes in the floristic composition of cerrado sensu stricto in Brazil over a nine-year period. Journal of Tropical Ecology, v.16, p.579-590, 2000. DOI: 10.1017/S0266467400001589.

FELFILI, M.C.; FELFILI, J.M. Diversidade alfa e beta no cerrado sensu stricto da Chapada Pratinha, Brasil. Acta Botanica Brasilica, v.15, p.243-254, 2001. DOI: 10.1590/S0102-33062001000200010.

HERNÁNDEZ-STEFANONI，J.L.; GALLARDO-CRUZ，J.A.; MEAVE, J.A.; DUPUY, J.M. Combining geostatistical models and remotely sensed data to improve tropical tree richness mapping. Ecological Indicators, v.11, p.1046-1056, 2011. DOI: 10.1016/j. ecolind.2010.11.003.

HERNÁNDEZ-STEFANONI, J.L.; GALLARDO-CRUZ, J.A.; MEAVE, J.A.; ROCCHINI, D.; BELLO-PINEDA, J.; LÓPEZ-MARTÍNEZ, J.O. Modeling $\alpha$ - and $\beta$-diversity in a tropical forest from remotely sensed and spatial data. International Journal of Applied Earth Observation and Geoinformation, v.19, p.359-368, 2012. DOI: 10.1016/j.jag.2012.04.002.

ISAAKS, E.H.; SRIVASTAVA, R.M. An introduction to applied geostatistics. New York: Oxford University, 1989. 560p.

LÍBANO, A.M.; FELFILI, J.M. Mudanças temporais na composição florística e na diversidade de um cerrado sensu stricto do Brasil Central em um período de 18 anos (1985-2003).
Acta Botanica Brasilica, v.20, p.927-936, 2006. DOI: 10.1590/ S0102-33062006000400016.

MAGURRAN, A.E. Measuring biological diversity. Oxford: Blackwell, 2004. 215p.

MELLO, C.R. de; VIOLA, M.R.; MELLO, J.M. de; SILVA, A.M. da. Continuidade espacial de chuvas intensas no estado de Minas Gerais. Ciência e Agrotecnologia, v.32, p.532-539, 2008. DOI: 10.1590/S1413-70542008000200029.

MELLO, J.M. de; BATISTA, J.L.F.; RIBEIRO JÚNIOR, P.J.; OLIVEIRA, M.S. de. Ajuste e seleção de modelos espaciais de semivariograma visando à estimativa volumétrica de Eucalyptus grandis. Scientia Forestalis, v.69, p.25-37, 2005.

MYERS, N.; MITTERMEIER, R.A.; MITTERMEIER. C.G.; FONSECA, G.A.B. da; KENT, J. Biodiversity hotspots for conservation priorities. Nature, v.403, p.853-858, 2000. DOI: $10.1038 / 35002501$.

NOGUEIRA, I. de S.; NABOUT, J.C.; OLIVEIRA, J.E.; SILVA, K.D. Diversidade (alfa, beta e gama) da comunidade fitoplanctônica de quatro lagos artificiais urbanos do município de Goiânia, GO. Hoehnea, v.35, p.219-233, 2008. DOI: 10.1590/ S2236-89062008000200005.

OKSANEN, J.; BLANCHET, F.G.; KINDT, R.; LEGENDRE, P.; MINCHIN, P.R.; O'HARA, R.B.; SIMPSON, G.L.; SOLYMOS, P.; STEVENS, M.H.H.; WAGNER, H. Vegan: community ecology package. [2013]. Available at: <http://CRAN.R-project.org/ package= $=$ vegan $>$. Accessed on: Oct. 22014.

OLIVEIRA, C.P. de; FRANCELINO, M.R.; CYSNEIROS, V.C.; ANDRADE, F C. de; BOOTH, M.C. Composição florística e estrutura de um cerrado sensu stricto no oeste da Bahia. Cerne, v.21, p.545-552, 2015. DOI: 10.1590/01047760201521041722.

PELISSARI, A.L.; FIGUEIREDO FILHO, A.; CALDEIRA, S.F.; MACHADO, S. do A. Geoestatística aplicada ao manejo de povoamentos florestais de teca, em períodos pré-desbaste seletivo, no estado do Mato Grosso. Revista Brasileira de Biometria, v.32, p.430-444, 2014.

PEREIRA, J.C; MOURÃO, D.A.C.; SCALET, V.; SOUZA, C.A.M. de. Comparação entre modelos de relação hipsométrica com e sem componente espacial para Pinus sp. na FLONA Ipanema, SP. Scientia Forestalis, v.39, p.43-52, 2011.

R CORE TEAM. R: a language and environment for statistical computing. Vienna: R Foundation for Statistical Computing, 2013. Available at: <http://www.Rproject.org>. Accessed on: Jul. 82014.

RIBEIRO JR, P.J.; DIGGLE, P.J. geoR: a package for geostatistical analysis. R-News, v.1, p.15-18, 2001.

RITTER, L.M.O.; RIBEIRO, M.C.; MORO, R.S. Composição florística e fitofisionomia de remanescentes disjuntos de Cerrado nos Campos Gerais, PR, Brasil - limite austral do bioma. Biota Neotropica, v.10, p.379-414, 2010. DOI: 10.1590/ S1676-06032010000300034

ROCCHINI, D.; HERNÁNDEZ-STEFANONI, J.L.; HE, K.S. Advancing species diversity estimate by remotely sensed proxies: a conceptual review. Ecological Informatics, v.25, p.25-28, 2015. DOI: 10.1016/j.ecoinf.2014.10.006. 
SCOLFORO, H.F.; SCOLFORO, J.R.S.; MELLO, C.R.; MELLO; J.M.; FERRAZ FILHO, A.C. Spatial distribution of aboveground carbon stock of the arboreal vegetation in Brazilian biomes of Savanna, Atlantic Forest and Semi-arid woodland. Plos ONE, v.10, p.1-20, 2015. DOI: 10.1371/journal.pone.0128781.

SCOLFORO, J.R.; MELLO, J.M. de; OLIVEIRA, A.D. de. (Ed.). Inventário florestal de Minas Gerais: Cerrado: florística, estrutura, diversidade, similaridade, distribuição diamétrica e de altura, volumetria, tendências de crescimento e áreas aptas para manejo florestal. Lavras: UFLA, 2008. 816p.

SERTEL, E.; KAYA, S.; CURRAN, P.J. Use of semivariograms to identify earthquake damage in an urban area. IEEE Transactions on Geoscience and Remote Sensing, v.45, p.1590-1594, 2007. DOI: 10.1109/TGRS.2007.894019.

WHITTAKER, R.H. Evolution and measurement of species diversity. Taxon, v.21, p.213-251, 1972. DOI: 10.2307/1218190.

Received on October 20, 2015 and accepted on May 20, 2016 